\title{
Language, identity, and ideology: Analysing discourse in Aceh sharia law implementation
}

\author{
Habiburrahim $^{1}$, Zainah Rahmiati ${ }^{1}$, Safrul Muluk ${ }^{1}$, Saiful Akmal ${ }^{1}$, and Zulfadli A. Aziz ${ }^{2}$ \\ ${ }^{1}$ Department of English Language Education, Universitas Islam Negeri Ar-Raniry, Jalan Syaikh AbdurraufNo. 1 \\ Darussalam, Banda Aceh 23111, Indonesia \\ ${ }^{2}$ Department of English Language Education, Universitas Syiah Kuala, Jalan T. Nyak Arief No. 441, Kopelma \\ Darussalam, Kec. Syiah Kuala, Kota Banda Aceh 23111, Indonesia
}

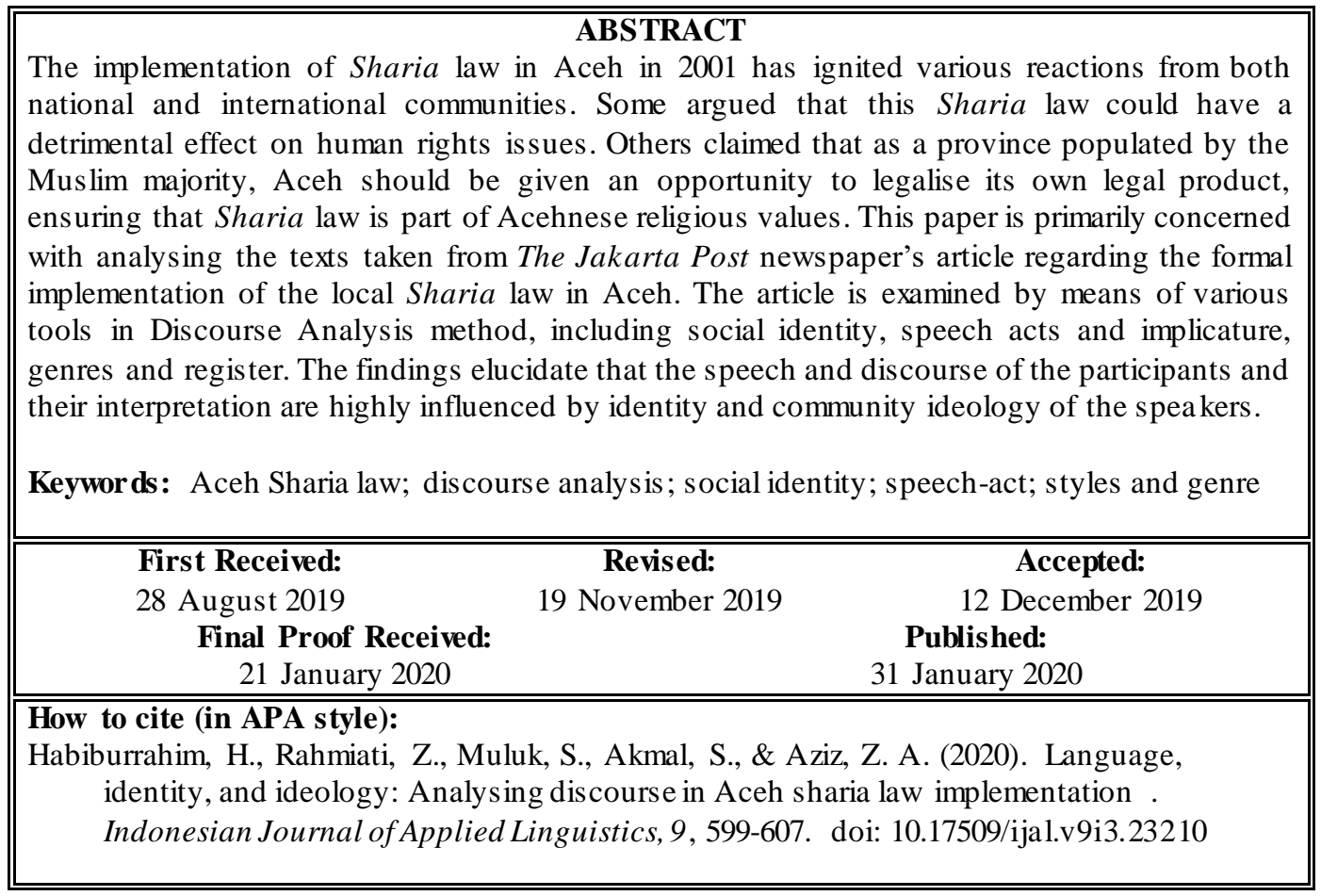

\section{INTRODUCTION}

Aceh is the northernmost province on Sumatra island in Indonesia and has a population of 5.96 million (Acehprov, 2017). During the $16^{\text {th }}-17^{\text {th }}$ centuries, Aceh was the major regional, political and commercial power under the Sultanate of Aceh and reached its glory during the ruling period of Sultan Iskandar Muda (1607 1636). Aceh experienced its decline after the death of the Sultan.

The story of the conflict in Aceh began during the invasion of Dutch colonialism in Sumatra and was followed by the Aceh War in 1873, which lasted for thirty years. By the late $13^{\text {th }}$ century, Islam had been established in the region of northern Sumatra, and Aceh became one of the first regions to embrace Islam. The long history of war during the period of Dutch colonialism further reinforced this "tradition of distinct identity" which was further influenced by cultural connections to Islamic values (Sherlock, 2003).
However, conflicts continued to occur long after Dutch colonialism was over. In 1976, Hasan Tiro established an armed pro-independence group, called the Free Aceh Movement (Gerakan Aceh Merdeka, GAM), as a basis for the campaign seeking independence from the Republic of Indonesia (Amnesty, 2013; Sherlock, 2003). The widespread mistrust of the government policies and centralised rules from Jakarta, the capital of the nation, was believed to have resulted in this armed conflict. The prolonged conflict was officially ended after the Helsinki Memorandum of Understanding (known as MoU Helsinki) was signed by both the government of Indonesia and GAM on 15 August 2005.

During the years 2000-2001, under the administration of President Abdurrahman Wahid, the central government took two significant steps to deal with the conflict in Aceh. The first was recognised as "Humanitarian Pause", and the second was the grant of

\footnotetext{
* Corresponding Author

Email: habib.habiburrahim@fulbrightmail.org
} 
"Special Autonomy" status to Aceh (Reid, 2004) in the passing of the law (44/1999). This policy was viewed as an establishment for the enactment of the new law, intended to provide a privileged status for the people of Aceh, to optimally run and implement local regulations in the region (Acehprov, 2017). Subsequently, the government also approved laws ratifying special autonomy in Aceh (18/2001), in conjunction with the application of the practice of Islamic law (Sharia law) and an Islamic court with jurisdiction over crime in the Aceh region (Hasan, 2007). In reality, the application of Sharia law faces multifaceted challenges, especially from groups of communities and organisations who wanted the government to take action to revoke the application, believing it to be against human rights.

As a consequence, the issues around the implementation of Sharia law in Aceh have received sustained interest, not only in national media but also worldwide. According to an article in The Jakarta Post (Simanjuntak \& Parlina, 2014), the Islamic Sharia law has been implemented even more strictly after December 2004, the year in which the tsunami disaster took place. This paper attempts to analyse the viewpoints of various stakeholders toward the implementation of Sharia Law in Aceh. The paper analyses some significant viewpoints of different stakeholders through a critical discourse analys is (CDA) approach.

\section{Discourse analysis}

Discourse analysis is an area of study in sociolinguistics. Linguists, to some extent, seem to use various terms in referring to discourse analysis. Discourse is simply defined as an instance of communicative actions in the medium of language (Johnstone, 2008; Risdaneva, 2014). Shaw and Bailey (2009) say that discourse is undertaken through language analyses including talks, interactions, symbols and documents. Meanwhile, a French social theorist, Foucault developed the idea of discourse by looking at the characteristics of an approach which emphasises the 'power of the relationship that is expressed through language and behaviour, and the relationship between language and power'. This definition seems to be more, interdisciplinary, comprehensive and closely interrelated in a way that language and power has a significant role in wider social practices and interactions (Usman, 2017).

However, there is a characteristic that significantly differentiates Critical Discourse Analysis (CDA) from Discourse Analysis (DA). The difference lies in the approaches used, specifically in the process of analysis, where it can act as a set of tools or methods to scrutinise the basic units of analysis, e.g., text, discourse, conversation, and speech acts. In terms of definition, CDA refers to the ways people explain social practices in social structures (Jaworski \& Coupland, 2006). Another definition was given to identify the objects of investigation, which commonly relates to social phenomena and its complexity rather than a linguistic unit (Wodak \& Meyer, 2009). Nevertheless, it appears to face a challenge in terms of the characteristics that connect language, power and ideology as it is described by Fairclough (2001) in his book 'Language and Power'. This opinion is similar to the idea advanced by Blommaert (2005), who suggests the importance of language as a way to comprehend elements of power relations in a broad context. He adds that critical discourse analys is should be an analys is of the effects of power, is used to determine the significance of power to people, groups, and societies, and how the effects of this power take place. On the other side, Machin and Mayr (2012) view this opinion as a constructive critique that may encourage linguists to develop approaches used in the CDA process, either methodically or theoretically.

With regard to the materials of the analysis available at The Jakarta Post article, we are, in this context, analysing the power relations arising from the discourse participants' standpoints on the implementation of Sharia law in Aceh. The close readings on their statements, wordings, and arguments towards the implementation of the Sharia law in Aceh are discussed in further details in the following section.

\section{Social identity}

The notion of social identity is one of the issues that must be looked at in scrutinising the context of the language. In relation to the notion of identity, de Fina (2006, p. 263) describes it as 'crucial, about conveying to one another what kind of people we are; which geographical, ethnic, social communities we belong to; where we stand in relation to ethical and moral questions; or where our loyalties are in political terms'.

Social identity is marked as a situation in which an individual or a group is categorised based on certain distinctive features, e.g. culture, skin colour, gender, biological sex, ethnicity, nationality, performance, etc. People tend to use schemes of cultural and social categorisation as a way to identify others who are seen to be particularly different from them, in a natural or predictable way. More often, working on the assumption has not always justified the real identity of the person.

In correlation with this, some of the linguists split the notion of identity and social identity as two separate concepts in the work of social categorisation (Tajfel, 1978). This concept of separation was supported by Hogg, Deborah, and White. (1995) who claimed that a social identity-theory is more into highlighting the importance of socio-cognitive process, contextual responsiveness, group behaviour and intergroup relations, and a clearer distinction between role and group. On the other hand, Burke and Stets (1998) argue that socio-cognitive discourse is also a part of social identity that is connected to the process of categorisation and depersonalisation, but not intensively highlighted since the theory of identity underpins the concept of behaviour.

In addition, Zotzmann and O'Regan. (2016, p. 1) state that 'the concept of identity ties in with the view 
that language use is not only a cognitive endeavour but likewise an immanently social one. The concept sensitises us to think about the reasons for and the conditions under which people use language, the way they are perceived by others as users of language, the meanings they want to convey in particular situations and the resources they draw upon in order to do so'. Meanwhile, identity signifies the result of the identification processes wherein others are deliberately or strategically dichotomised based on their similarities and dissimilarities (Johnstone, 2008). Very often, social identities are connected with the roles of participants in society. Social identity is then, according to Duszak, "part of an individual's self-concept that came from the knowledge of his/her membership in a social group, together with emotional significance attached to it" (2002, p. 2).

The five discourse participants' social status or categorization is likely representing the way they argue on the Sharia law implementation in Aceh, take, for example, Abdullah Saleh, Zaini Abdullah and Irwandi Yusuf. It is inevitable that they represent their political affiliation, status in the organizational hierarchy of a political party or government's entity. The political language in a newspaper, as Akmal (2017) argued, is often embodied in their subjective arguments and expressed in speech acts, be it for their political campaign or for other political causes. On the other hand, Saifuddin Bantasyam and Didik Suprayitno remarking on the same is sues are very much considered as the representation of the academia and the national government that might see the issue from different angles.

\section{Speech acts}

Speech acts are performed by a speaker when using a language (Searle, 1985). Sometimes, when we read a book or a newspaper, it might come across our mind what the writer actually means by his words, why he talks or writes in a certain way and then why is it necessary to write like this and not like that. Are there any implications (also known as implicature) behind the messages or correspondences? How can the message or corres pondence affect readers or audiences?

The speech act is often referred to as the concept of "illocutionary act". The notion of the illocutionary act was originated by Austin (1975) and his pupil, H. Paul Grice and was later developed by the scholar, John Searle (Searle, 1968). Austin and Grice studied in the school of Ordinary Language at Oxford. Their attempts to discover the phenomenon behind conversational implications or implicature in daily communication was highly valued as a foundation of the theory of locutionary, illocutionary, and perlocutionary acts. For this contribution in the field research of psycholinguistics, Austin and Grice are then acknowledged as 'language philosophers' (Thomas, as cited in Bowe, 2014, p. 9).

In his research, Austin was trying to differentiate between "what a speaker says, what the speaker actually means, and what the hearer thinks the speaker means" (Bowe, 2014). Illocutionary acts have a close connection with locutionary acts (Searle, 1968) but are distinct in traits and elements of action. Illocutionary is described as an act "performed in saying something", locutionary act places emphasis on the act of saying something and perlocutionary acts deal with an act performed by saying something (Austin, 1975) that occurs mostly in a real-life discourse and interaction. In this paper, the writers will briefly focus on discussing the locutionary and illocutionary acts on writing.

\section{Genre}

Genre is derived from a French word which literally means "kind". There are several definitions that have been given to describe the genre. For example, Miller (1984) defines the genre as a typification of social and rhetorical action, whilst Swales (1998) views genre as part of the consistency of communicative purposes. The analysis of genre is closely linked with the study of literacy, but nowadays, it has been utilised in many fields of studies such as linguistics, socio-politics, and anthropology. Genre analysis also reflects social role and function in the community as an ideology. Additionally, Johnstone (2008) suggests that a genre in writing helps recognise, reproduce, and manipulate a speech so that the speaker would be acknowledged as a knowledgeable individual from a specific community group.

However, the determination of genre in writing is not as simple as it is assumed. An analyst needs a particular set of knowledge to encode the language in a text, discover the facts behind discourse structures, and most importantly, to find out the conventional types of communication or interaction that represent the purpose of the discourse. These activities can be performed through the work of analysing the form of the text, as well as, and the actions occur as an implication of the discourse. Furthermore, the analyst can divide the genre of the text into certain categories, e.g., legal text, formal text, academic prose and etc. (Johnstone, 2008).

\section{Register}

Register has been generally used in Sociolinguistics. Linguists define register as a set of lexical (vocabulary) and grammatical features that accompany and help determine discourse that occurs in a particular recurrent situation (Johnstone, 2008). The term register refers to varieties of languages use that is slightly different from the term dialect, which focuses on the language user (Hudson, 1980). In other words, register is the use of language in a particular social setting for a particular purpose of writing.

The level of formality in writing is usually recognised from register or style adopted by the article's writer in his writing text. It is, somehow, not easy to distinguish between register and style. Labov (1973) however, differs style from register in a way that a style is associated with the speaker's degree of selfconsciousness. It is also believed that style refers to 
lexical choices and knowledge of grammar in a register (Johnstone, 2008).

\section{METHOD}

This paper adapts the dimensions of discourse studies introduced by Wodak (2015). First, the phenomena of text grammar and language use. In this aspect, the paper focuses on the description and interpretation of speech acts and implicature. This speech acts and implicature will be analysed by referring to the arguments provided by five discourse participants. Second, it seeks out to reveal the function of texts constructed around social identity by analysing the context of language use. More specifically, the analys is of cultural and social representation in Aceh as well as the genres and styles use in particular settings is applied in this paper (Bhatia, 2014). For example, how academia from university, in this case, Saifuddin Bantasyam puts forward his arguments in dealing with the new regulation ratified by the central government in Jakarta.

The material of analysis is taken from a nationallycirculated English newspaper the Jakarta Post. The data were obtained from the article entitled "Aceh fully enforces Sharia" published by the newspaper on Friday, February 7, 2014, which can be read on https://www.thejakartapost.com/news/2014/02/07/acehfully-enforces-sharia.html. The news article was written and reported by the newspaper's contributors Hotli Simanjuntak and Ina Parlina. The writers believe that this newspaper material could provide balance information and perspective regarding the implementation of Sharia law in Aceh as the paper was written and reported by independent writers and reporters who do not have any affiliation with Aceh government nor with any nongovernmental organization supporting or rejecting the issues of Sharia law implementation in this region. Besides, the discourse participants involved in such the newspaper hold different formal positions and are from various legal institutions as well.

There were five names of discourse participants mentioned in the article, and two of them were the governors (e.g Zaini Abdullah, a former governor, and Irwandi Yusuf, an active governor of Aceh). The other three were Abdullah Saleh, a parliament member, Saifuddin Bantasyam, a legal observer and social scientist from Syiah Kuala University, Banda Aceh, and Didik Suprayitno, the Home Ministry spokesman. These last three participants came from different institutions, interests, and roles in society which supposedly lead to a different way of presenting arguments and point of views. The findings are elaborated in four main themes: social identity and identification, speech acts and conversational implicature, genre, and register.

\section{FINDINGS AND DISCUSSION}

This paper does not have any intention to provoke any political friction on the implementation of Sharia Law in Aceh; rather discuss the diverse perspectives from different discourse participants with regard to such the issue. The findings are summarised in four major predetermined themes related to discourse analysis studies, social identity and identification, speech acts and conversational implicature, genre, and register: language styles for situations.

\section{Social identity and identification}

One of the is sues that might be raised here is whether the participants' identity in the article would be recognized as an individual or as a member of a social group. Within the context of the newspaper, Abdullah Saleh's is a parliament member; Saifuddin Bantasyam is a legal observer and Didik Suprayitno as spokesman of Home Ministry. This influences the style and features of discursive acts of a certain performance (Perinbanayagam, 2017).

For example, Abdullah Saleh is Acehnese by origin. Thus, his way of thinking is influenced by a common categorisation of ethnicity, religion, political attitude, norms and tradition that is applied in Aceh province. His non-negotiable, strict and inflexible approach is vivid.

Discursive performance of an individual's identity is shaped by the goal of the corres ponding message too. It can go, to some extent, "beyond the lexicon" or the verbal discourse (Howard, 2009). For instance, why the participant should say this, instead of that and what effects and consequences can be possibly found behind the messages. Strategically, discourse participants will not be happy when the messages sent through their speech or discourse have left no effects on the audience, or the meaning is biased and does not encounter the purpose of the discursive performance.

Distinguishing, each of the participants in the article can be performed by looking at their identities and how this is connected to their sense of social identity in the community. Abdullah Saleh is acknowledged in the newspaper as a parliament member who works at the Aceh provincial administration and legislative council. This institution has a very important role in the local government's decision whether to approve or disapprove the Qanun Jinayat (behaviourgoverning bylaw) relating to the implementation of Sharia law in Aceh. The first paragraph has indicated that Abdullah Saleh was one of the members who contributed to the forum discussion on the qanun in the council. Considering the fact of his participation in the discussion, Abdullah Saleh plays a pivotal role in shaping and influencing public opinion towards the implementation of qanun in Aceh. As it is displayed in the article, the discourse that is expressed by Abdullah vividly shows the 'power of identity' of his role in that governmental institution. For example, in one of his statements, he argues: "It would be unfair if Muslims were punished while non-Muslims violators were not treated under the same law for the same violations".

This is similar to what has been outlined by Tannen (1981) that ethnicity is considered to be one conversational style in discourse. Saleh, in this excerpt, 
affirms that the implementation of Sharia must be obeyed by both the Muslim and non-Muslim. On behalf of "equality before the law", he maintains that the penalty for Sharia-offenders will be applied noncategorically. His categorization of Muslim and nonMuslims are, to some regards, socially constructed by his long attachment to the traditional ideology of the Aceh Party. The party was a political concession found in a post-conflict setting, and it was mainly the stay for the ex-combatants' chain of command in the political arena. It is inevitable, so to say, that they are having very low acceptance of external ideas, ideologies and perspectives in the post-conflict debates. Their "native interpretation" of an event, issue and term must be, one way or the other, forcefully constructed within the rigid social construct and identification. It may be strategically used to reinforce his speech as a councillor or parliament member. Also, it could otherwise be considered solely as an individual's performance. This can be seen as a way to shape the speaker's identities in which they are used in discourse (Shotter \& Gergen 1989).

By contrast, Saifuddin Bantasyam, as mentioned previously, works as an observer on legal issues and a social scientist at Syiah Kuala University in Banda Aceh. The image of an observer and scientist are an entirely distinctive profession from a "legislator". It may imply that Abdullah Saleh and Saifuddin Bantasyam are opposing each other when it comes to making statements. The features of the discourse performance of these two persons adopt different emphasis and purpose, as either an individual or associated with the group. Saifuddin seems to have more freedom to express his opinion since his job as an "observer" is supposed to provide critical views and critiques on particular issues that were raised and that occurred in society. This kind of opinion can be seen from one of his quotes: "It would be awkward if Islamic law was applied to non-Muslims regardless of whether the violation was categorised as a Sharia violation".

Furthermore, a discursive performance of an "observer" which may involve a set of linguistic performance and rhetorical style is commonly identified as a personal identity without referring to any of the specific groups. Therefore, in reality, the two persons may interact using a particular strategy of speech acts such as politeness, criticising, and offending each other. The issues on speech acts will be discussed further in the following section. In the word of Fowler (1986), the language of criticism is a useful discourse analysis tool to evaluate the verbal discourse within the political setting.

Didik Suprayitno seems to be the only nonAcehnese participant featured in the article. He works as a spokesman at the Ministry of Home Affairs, Indonesia. Similar to Abdullah, Didik, is a spokesman which means a representative of the institution he is working for. Therefore, his speech is highly valued as a group member's decision, instead of as an individual's statement. Moreover, at the level of a Ministry, the pattern of the discursive performance is usually designed to employ some elements of institutional identities and power and to be allied strictly with national regulation. On the other hand, the statement will be such a "powerful" signal to confirm the application of Sharia law in Aceh. He says: "Basically all local regulations must be in line with national laws". And then he adds: "All local regulations should be reviewed first by his office".

In other words, the local government of Aceh cannot use its 'power' to reinforce and implement the local Sharia law without being approved by the central government. It obviously shows that as a performance, identity cannot be separated from a person who performs the action and a social community where the performance of communicative action takes place. From Ochs perspective (1993), to construct someone's social identity and language socialisation (in public places), the context will be especially embedded by the speaker.

Apart from the identity of the speakers, The Jakarta Post, the mass media publishing this article, is also worth discussing. The Jakarta Post is a daily newspaper presented in the English language. This Jakarta-based newspaper is owned by a company named PT Bina Media Tenggara. As an English written broadsheet newspaper, The Jakarta Post targets specific middle-high groups of readers, particularly educated Indonesian and foreigners. Learning from that experience, the founder attempted to serve a non-bias news source to the public in Indonesia and globally (Tarrant, 2008).

As an independent newspaper, The Jakarta Post's main aim should be to serve people with good quality news (par excellence broadsheet newspaper), whilst committing to promote, uphold and maintain views which may be in contradiction with certain situations or interests of other parties. On the other hand, it is essential to consider the use of language choice and other elements of structure and content of discourse written in articles, because 'the power of language' can influence public perceptions in different ways.

\section{Speech acts and conversational implicature}

In illocutionary speech acts, people tend to hide their intentions of saying what they intend to say, as a strategy to reduce the sense of being impolite. In this situation, they normally use certain verbs, such as performative verbs, which have to be interpreted according to the situation in order to avoid ambiguity. This can be seen from several examples in the article. The first example comes from Abdullah Saleh, who says that: "The qanun does indeed oblige everyone in Aceh to
follow Sharia, the Islamic legal code".

The performative verb (Condoravdi \& Lauer, 2011) used here is "oblige" which has put a very strong emphasis on how the qanun should be treated by the Acehnese people. This locutionary interpretation is very clear in affirming how Sharia law in Aceh is being 
implemented to serve the people as a whole in Aceh, so it is not a matter if you are an Acehnese or not.

Speaking about the communicative purposes, the discourse participants view of the implementation of Sharia law in Aceh in at least two standpoints. First, it should not be against the local nor national law. Second, the implementation of Sharia law in Aceh must also abide by international human rights or other humanitarian acts as it has been depicted in the first two paragraphs above.

However, in the sense of the illocutionary act, this performance of utterance may be understood differently by those who live outside Aceh, non-Muslims in particular. It can be regarded as law reinforcement since it stemmed from an active verb of "oblige". At the same time, the chosen verb may be seen to have additional meaning and connotation by outsiders or non-Muslims to be associated with any kind of fundamental policy. In some senses, the statement also may implicitly contain ambiguous points of view "locutionary acts" in which the readers understand the utterance differently based on their own assumptions or guesses. For instance, Aceh seems to be very strict in terms of maintaining local norms and cultures, making it a culturally inclusive area. Similarly, the statement may implicitly suggest a warning to non-Aceh people that would want to visit Aceh that they should comply with qanun, and thus, they should not commit anything that may lead to violation of qanun such as "drinking alcohol or doing affectionate contact with an unmarried couple" (Simanjuntak \& Parlina, 2014).

In response to this statement, a Chinese-descent resident identified as a Buddhist speaks up:

"I'm of Chinese descent and not a Muslim, why should I obey Islamic teachings? As far as I know the headscarf is for Muslim women".

Impartially, illocutionary act here suggests action from the speaker to present by elaborating his words and ideas (Johnstone, 2008) which allow the utterance to be interpreted differently. For example, how can Sharia law, an 'Islamic regulation' that is specifically designed to treat Muslims, be equally enforced to treat non-Muslims? He thinks that this policy is fairly unjust considering his position as an Aceh resident, but only from a different ethnic and religious background.

The first two statements made by Abdullah Saleh reads as follow:

"The qanun does indeed oblige everyone in Aceh to follow Sharia without exception.... But, if the violation committed by a non-Muslim is not regulated in the $K U H P$, then the violator will automatically be tried in a Sharia court, without exception".

The first statement from Abdullah Saleh's literally contains a warning implicature with regard to Sharia application, whilst the second statement shows an attitude of defence or deterring aggression against the first statement. Having said that, this paper cannot be used to claim whether the statements are true or false, but rather to analytically show the power relation between the speakers and how their statements reproduced (Van Dijk, 1995).

\section{Discourse structure}

In this section, the writers discuss how discourse is constructed by various kind of segments and how these segments conventionally affect the use of the discourse (Johnstone, 2008). Additionally, the clauses, phrases and sentences are not only utilised to determine the flow of certain information from discourse but also to help structure the intended meaning of the discourse. In examining discourse structure in this article, the writers look particularly at other contexts, such as genres of writing, what kind of language is used in particular contexts or purposes in conjunction with the register. For the purpose of discussion and its relation to the newspaper article, the following section discusses the genre of writing.

\section{Genre}

Martin (1992) views genre as "text types", whereas Jones (2012) formulates genre as both "discourse in action" and more specifically as "communicative actions". In this article, the views from those experts are used as our main references to analyse the news article. Thus, there are some steps that can be employed to categorise this article into a particular genre of community discourse. First of all, the writers analyse the topic of the written-text as sociated with the current situation in Aceh and see how it fits into any kind of a socio-cultural framework. There seems to be an important question to ask; has the discourse represented any particular community ideology? Answering this question assists in identifying social and cultural contexts embedded in the text that affect the interpretation of the discourse. Most crucially, the writers are able to see the purpose that the genre serves.

From the article entitled "Aceh fully enforces Sharia", the writers can fully capture the implication of the discourse in the main topic about the application of Sharia law in the territory of Aceh. Some of the newspaper readers may be aware of this issue when looking at the title and perhaps they may also guess what the writers are trying to propose. If we look at the structure form of the title, it consists of 2 nouns, 1 adverbial word and 1 verb. The first noun is Aceh, naming the area where the Sharia law is implemented. The word Sharia (usually written as shari'a) is derived from an Arabic word, meaning the traditional system of Islamic law (Macmillan, 2002). These formal features can be seen from several words choices in the text. In terms of repetition, the article mentioned the word Sharia sixteen times in total to show that the word plays a significant role in the story they wrote. This is, perhaps, to deliberately frame the readers' attention to gain general information on what they are reading. Besides the word Sharia, another specific word used to attract the readers to read further is the word "fully" and "enforce". The word "fully" is a synonym for "entirely" and "completely". Whilst in this context, it might imply 
that there is no room for flexibility for the application of Sharia law in Aceh. Last but not least, the word 'enforce' is an active verb to describe a communicative action (Johnstone, 2008). Macmillan dictionary (2002) explains the word as an action to make sure that a law or rule is obeyed by people. The meaning of the word may be perceived as obedience when it is connected to the context of cultures and traditions in Aceh, which is mostly influenced by Islamic values. Though, other community groups in society may see it negatively as pressure or an oppression wherein the people of Aceh must accept it, like or dis like.

Apart from the title, it seems that the authors of this newspaper article were trying to frame some elements of discourse's form and structure in order to present the stories in detail. The text began with a topic sentence: "The Aceh provincial administration and legis lative council have approved the Qanun Jinayat..."

This entails a key point of the whole story. It may give clue information to fulfil readers' curiosity on what will be happening when Qanun Jinayat is approved. What does Qanun Jinayat entail? Where is the implementation to be carried out? How it is going to be applied? Has the Qanun Jinayat affected a particular religion or other cultural community groups? These initial questions may lead to an intense inquiry by the readers to further read the article.

Having read through the whole story, the writers could see the exploration of the ideas of Islamic Sharia law is being implemented by presenting a number of influential figures (discourse participants) to give stronger public opinions or arguments on the application of Islamic Sharia law. Their involvements supposedly provide a contribution on how the Qanun Jinayat should be applied in the community and why that is significant to do. The function of the genre also generates the values of local ideology in the context of maintaining Islam as a religion. Despite this ideology, the implementation of the law remained debatable amongst Acehnese legislative members. This controversial reaction can be seen from a sentence in the second paragraph of the article stating that the acting governor, Irwandi Yusuf, declined to impose the implementation of the law under his governance.

\section{Register: Language styles for situations}

In connection with this point, we provide several examples of lexical choices from the article. Within a 771-words essay, the word Sharia appeared 15 times, qanun 12 times, 'law' 10 times, 'violations' 9 times, 'court' 9 times, 'code' 7 times, and 'criminal' 4 times (Simanjuntak \& Parlina, 2014). The following is the sample in which the "Sharia" entry was found. "But, if the violation committed by a non-Muslim is not regulated in the KUHP then the violator will automatically be tried in a Sharia court, without exception".

It can be clearly observed that the repetition of words in the phrases and sentences precisely identified that the authors of the newspaper article were trying to highlight legal is sues as their strong argumentation. The lexicon also helps explain to readers the kind of situation in which the interaction is taking place, even though the readers are very likely or are not familiar with legal terms.

Having understood the authors' styles and the use of language in this particular setting, it is safe to say that readers are well informed about the communicative purpose of their writing. In brief, the language used in this social context is a legal language which is often known as legalese (Johnstone, 2008). In terms of register, the writers adopted a "formal" style of language to adjust to the situation and purpose of the interaction in the article. The interviews with the discourse participants were the main source of information provided by the author's article in The Jakarta Post newspaper. The functional variation of specific lexical and grammatical selection presented in the article are clearly categorized into the formal variety use (Halliday, 1989), and indirect interaction or discourse through the writing of news articles (Van Dijk 2013).

\section{CONCLUSION}

There are several points to highlight after having finished analysing the article "Aceh fully enforces Sharia". The use of discourse analysis as a tool in this paper enabled the analysis to generate meaningful inferences behind the speech and discourse of each participant. The interpretations are highly influenced by the identity and the ideology of the speakers. Simultaneously, it helps us to find out the writers' messages and purposes of writing by examining the genre and styles of the writers with regard to register.

To some extent, the authors of the newspaper article showed their efforts to be impartial on the issue of the implementation of Sharia law by presenting several discourse participants from various social and professional backgrounds. Otherwise, the purpose of writing could be regarded as subjective and biased as it may indicate their opposition to the implementation of Sharia law. Also, a very strong viewpoint was made by one of the discourse participants, Abdullah Saleh, which reflects his authority on the issue and also the ideology of the Acehnese community that is strongly associated with Islamic principles. Concurrently, it triggers some opposite reactions from other parties, including the legal observer, Saifuddin Banstasyam, and the spokesman of the Home Ministry, Didik Suprayitno, as a nonAcehnese ethnic resident.

\section{REFERENCES}

Acehprov.(2017). Jumlah penduduk Aceh menurut kabupaten/kota tahun 2006 - 2016. Retrieved from https://aceh.bps.go.id/dynamictable/2017/09/08/18 9/proyeksi-jumlah-penduduk-aceh-menurutkabupate-kota-2006-2017.html 
Akmal, S. (2017). The language of political campaign in post-civil war muslim society. ARICIS, 1(1), 683690.

Amnesty. (2013). Indonesia: Victims of the Aceh conflict still waiting for truth, justice and reparation. Retrieved from https://www.amnesty.org/en/latest/news/2013/04/i ndonesia-victims -aceh-conflict-still-waiting-truthjustice-and-reparation/

Austin, J. L. (1975). How to do things with words. Oxford: Oxford University Press.

Berutu, G. A. (2014). Aceh dan syariat Islam. Jakarta: Universitas Islam Negeri Syarief Hidayatullah.

Bhatia, V. K. (2014). Analysing genre: Language use in professional settings. London: Routledge.

Blommaert, J. (2005). Discourse: A critical introduction. Cambridge: Cambridge University Press.

Bowe, H. J. (2014). Communication across cultures: mutual understanding in a global world ( $2^{\text {nd }}$ edn.). Port Melbourne, Vic.: Cambridge University Press.

Burke, P. J., \& Stets, J. E. (1998). Identity theory and social identity theory. Paper presented at the Social Psychology Section Session on Theoretical Frameworks, San Francisco.

Condoravdi, C., \& Lauer, S. (2011). Performative verbs and performative acts. Proceedings of Sinn und Bedeutung, 15(1), 149-164.

de Fina, A. (2006). Discourse and identity. In de Fina, A., Schiffrin, D., \& Bamberg, M. S. (Eds.), Discourse and identity (pp. 263-282). Cambridge: Cambridge University Press.

Duszak, A. (2002). Us and others: An introduction. In: A. Duszak (Ed.), Us and others. Social identities across languages, discourses and cultures (pp. 128). Amsterdam: Benjamins.

Fairclough, N. (1992). Discourse and social change. Cambridge: Polity Press.

Fairclough, N. (2001). Language and power ( $2^{\text {nd }}$ edn.). Harlow: Longman.

Fowler, R. (1986). Linguistic criticism. Oxford: OUP.

Halliday, M. A. K. (1989). Spoken and written language. Oxford: Oxford University Press.

Hasan, N. (2007, October). Islamic militancy, Sharia, and democratic consolidation in post-Suharto Indonesia. Paper presented at IDSS/Working Papers, Singapore, Nanyang Technological University.

Goffman, E. (1959). The presentation of self in everydaylife. Garden City, N.Y: Doubleday.

Hogg, M. A., Deborah J. T., \& White, K. M. (1995). A tale of two theories: A critical comparis on of identity theory with social identity theory. Social Psychology Quarterly, 58(4), 255-269. doi: 10.2307/2787127

Howard, R. (2009). Beyond the lexicon of difference: discursive performance of identity in the Andes. Latin American and Caribbean Ethnic
Studies, 4(1), 17-46. doi: 10.1080/17442220802681415

Hudson, R. A. (1980). Sociolinguistics. Cambridge, New York: Cambridge University Press.

Jaworski, A., \& Coupland, N. (2006). The discourse reader $\left(2^{\text {nd }}\right.$ edn.). London: New York: Routledge.

Johnstone, B. (2008). Discourse analysis ( $2^{\text {nd }}$ edn.). Malden, MA: Blackwell.

Jones, R. H. (2012). Discourse in action. In Chapelle, C. (Ed.), The encyclopedia ofapplied linguistics (pp. 106-125). Oxford: John Wiley and Sons, Inc.

Labov, W. (1973). Sociolinguistic patterns. Philadelphia: University of Pennsylvania Press.

Machin, D., \& Mayr, A. (2012). How to do critical discourse analysis: A multimodal introduction. Los Angeles: SAGE.

Macmillan. (2002). Macmillan English dictionary. Britain and the United States: Macmillan.

Martin, J. R. (1992). Genre and literacy-modeling context in educational linguistics. Annual Review of Applied Linguistics, 13(1), 141-172. doi: 10.1017/S0267190500002440

Miles, M. B., Huberman, A. M., \& Saldana, J. (2014). Qualitative data analysis ( $3^{\text {rd }}$ edn.). Thousand Oaks: SAGE.

Miller, C. (1984). Genre as social action. Quarterly Journal of Speech, 70(2), 151-167. doi: $10.1080 / 00335638409383686$

Ochs, E. (1993). Constructing social identity: A language socialization perspective. Research on language and social interaction, 26(3), 287-306. doi: 10.1002/9780470758434.ch6

Perinbanayagam, R. (2017). Discursive acts; Language, signs, and selves ( $2^{\text {nd }}$ edn.). New York: Routledge.

Reid, A. (2004). War, peace and the burden of history in Aceh. Asian Ethnicity, 5(3), 301-314. doi: 10.1080/1463136042000259761

Risdaneva. (2014). Exploring interpersonal interaction in written discourse. Englisia: Journal of Language, Education, and Humanities, 2(1), 6069. doi: 10.22373/ej.v2i1.322

Searle, J. R. (1968). Austin on locutionary and illocutionary acts. The Philosophical Review, 77(4), 405-424. doi: 10.2307/2183008

Searle, J. R. (1985). Expression and meaning: Studies in the theory of speech acts. Cambridge University Press.

Shaw, S. E., \& Bailey, J. (2009). Discourse analysis: what is it and why is it relevant to family practice? Family Practice, 26(5), 413-419. doi: 10.1093/fa mpra/c mp038.

Sherlock, S. (2003). Conflict in Aceh: A Military Solution? Retrieved from http://www.aph.gov.au/binaries/library/pubs/cib/20 02-03/03cib32.pdf.

Shotter, J. , \& Gergen, K. J. (1989). Texts of identity. Sage Publications, Inc.

Simanjuntak, H., \& Parlina, I. (2014, February 7). Aceh fully enforces Sharia. The Jakarta Post. Retrieved from 
https://www.thejakartapost.com/news/2014/02/07/ aceh-fully-enforces-sharia.html

Swales, J. M. (1998). Different floors, different voices: A textography of a small university building. Mahwah, NJ: Lawrence Erlbaum.

Tajfel, H. (1978). Differentiation between social groups: Studies in the social psychology of intergroup relations $(E d$.). London: Academic Press.

Tannen, D. (1981). Indirectness in discourse: Ethnicity as conversational style. Discourse processes, 4(3), 221-238. doi: 10.1080/01638538109544517

Tarrant, B. (2008). Reporting Indonesia: The Jakarta post story [1983-2008]. Jakarta: Equinox Publication. humanities, 4(2), 116-130. doi: 10.22373/ej.v4i2.1667

Van Dijk, T. A. (2013). News as discourse. New Jersey: Routledge.

Van Dijk, T. A. (1995). Aims of critical discourse analysis. Japanese Discourse, 1(1), 17-28.

Wodak, R. (2015). Methods of critical discourse studies. London: SAGE

Wodak, R., \& Meyer, M. (2009). Methodsfor critical discourse analysis. London: SAGE.

Zotzmann, K., \& O'Regan, J. (2016). Critical discourse analysis and identity. In, Preece, S. (Ed.), The Routledge handbook oflanguage and identity (113-127). London: Routledge.
Usman, J. (2017). Metaphors in the ex-GAM's political discourses during pre-public elections in Aceh. Englisia: Journal of language, education, and 